\title{
Synergistic Effect Of A Retinoid X Receptor-Selective Ligand Bexarotene And Docetaxel In Prostate Cancer [Corrigendum]
}

Shen D, Wang H, Zheng Q, et al. Onco Targets Ther. The authors apologize for this error. 2019;12:7877-7886.

Upon reviewing the article, the authors noticed an error in two of the authors name (page 7877). The correct author names are Liqun Xia and Gonghui Li.

\section{Publish your work in this journal}

OncoTargets and Therapy is an international, peer-reviewed, open access journal focusing on the pathological basis of all cancers, potential targets for therapy and treatment protocols employed to improve the management of cancer patients. The journal also focuses on the impact of management programs and new therapeutic agents and protocols on patient perspectives such as quality of life, adherence and satisfaction. The manuscript management system is completely online and includes a very quick and fair peer-review system, which is all easy to use. Visit http://www.dovepress.com/ testimonials.php to read real quotes from published authors. 